\title{
The Preparation and Biological Toxicity Research of the New Controlled Release Carrier Nano-silica
}

\author{
Xinxin $\mathrm{Li}^{\mathrm{a}}$, Wenjuan zhang ${ }^{\mathrm{b}}$, Bobo Tong ${ }^{\mathrm{c}}$, Xiang Zheng ${ }^{\mathrm{d}}$, Yali Zhao ${ }^{\mathrm{e}}$, Zhilong Wang ${ }^{\mathrm{f}^{*}}$ \\ Gansu university of traditional Chinese medicine, Lanzhou730000, Gansu, China \\ a441004209@qq.com, 'b zhangwenjuan.0202@163.com, ${ }^{\mathrm{c}} 1452690227 @ q q . c o m,{ }^{\mathrm{d}} 2458895945 @$ qq.com, ${ }^{\mathrm{e}} \mathrm{lkzyl} @ \mathrm{gszy} . \mathrm{edu} . c n$, \\ fwangzhilong@gszy.edu.cn
}

\begin{abstract}
The different particle sizes' nano silica spheres are synthesized by the TEOS hydrolysis method. The XRD patterns testified that the sample is single phase and its strongest peak is significantly broadened. From the photos of TEM we can see that the samples' surfaces have a good dispersion and uniform spherical morphology. The Hela cell proliferating activity is assessed by MTT assay, combined with the cell morphology and Annexin Hoechst 33342 staining are employed to determine apoptosis in Hela cells. Results shows that while the Hela cell treated with different concentrations of $200 \mathrm{~nm}$ nano silica, cytocompatibility becomes better with the lower concentrations of nano silica. $24 \mathrm{~h}$ cells stained photograph shows that under the concentrations of nano silica $50 \mu \mathrm{g} \cdot \mathrm{ml}^{-1}$ the cell structure is normal and nucleus is complete.
\end{abstract}

Keywords- TEOS hydrolysis method; nano silica; biocompatibility

\section{INTRODUCTION}

Nano silica is a kind of inorganic materials with nanoscale size holes, the aperture size in a range from several nanometers to tens of nanometers. Nano silica itself can show the Quantum-Size Effect and Macroscopic Quantum Tunneling Effect when the radius of the silica particles reach nanoscale. The nano silica has a broad application prospect in terms of drug controlled-release and sustained-release carrier, because of its small particles, specific surface area, high surface reactivity, active center and high adsorption features. The preparation of $\mathrm{SiO}_{2}$ nanoparticles mainly includes physical methods and chemical methods. The physical method is the mechanical crushing method in general. The smaller micron grade products can obtained by grinding the $\mathrm{SiO}_{2}$ aggregates in use of the super jet mill or Simoloyer mill. Chemical methods include ion exchange method, precipitation method, chemical vapor deposition method, liquid phase method and sol-gel method, etc. Compared with the physical methods, chemical methods can produce ultrafine $\mathrm{SiO}_{2}$ particles $^{[1-6]}$.In 1992, the silica zeolite M41S which can be used in gene transfection and drug carrying was found in the research team led by Dr. Kresgebo in their study, and their report was published in the journal Nature of the year. Under some special conditions, the silica zeolite M41S can effectively regulate the permeability of nano silicon dioxide carrier capsule wall for drug release based on certain stimulation mechanism, the release rate can be adjusted through the rate of diffusion through the wall of the nanocarrier guest drug molecules. In 1983, the concept of the magnetic targeting drug delivery system was be proposed $^{[7]}$, and further recognized $\mathrm{SmIgG}^{+} \mathrm{B}$ lymphocytes,HepG hepatoma cells, WA systemic lupus erythematosus cells and leukemia cells ,etc ${ }^{[8,9]}$. In recent years, the research of nano silicon dioxide developed rapidly, after 2005,Vallet-Regi,etc, systematically studied the influence of different sizes, mesoporous structure, surface area and mesoporous volume to the drug-loading capacity and the drug release rate of nano-silica ${ }^{[10,11]}$. Since 2007, our country have done a lot of research on Hela toxicity of $\mathrm{SiO}_{2}{ }^{[12]}$, and later, the research of the magnetic functionalization and fluorescent markers of functional nano-silica as targeted transport and biomarkers materials has always been rising. From 2012 to 2014, our country has explored nano-silica compound used as gene transfection carrier ${ }^{[13]}$, and has a number of studies in the $\mathrm{SiO}_{2}$ particle size and its toxicity to different cells ${ }^{[14,15]}$.In this experiment, we prepared the nano-silica with TEOS hydrolysis method, studied its in vitro cytotoxicity, and looked forward to having more applications in medicine.

\section{EXPERIMENT}

\section{A. The preparation of nano silica spheres}

Nano silica spheres were synthesized through ethyl silicate hydrolysis method. The starting materials were TEOS (92.9\%-93.6\%), $\quad \mathrm{CH}_{2} \mathrm{CHOH} \quad(>99.0 \%)$, $\mathrm{NH}_{4} \mathrm{OH}(>99.0 \%)$. All the reagents used were analytical grade. TEOS: $\mathrm{CH}_{2} \mathrm{CHOH}(1: 4)$ mixed solution $\mathrm{A}, 500$ $\mathrm{r} / \mathrm{min}$ stir $4 \mathrm{~h}$ by constant temperature magnetic stirrer to get emulsion, and slowly add distilled water (distilled water: solution $=7: 1$ ) in A solution to get solution B. Using $\mathrm{NH} 4 \mathrm{OH}$ adjust $\mathrm{pH}$ of solution $\mathrm{B}$ to get solution $\mathrm{C}$, then placed in drying oven, $80^{\circ} \mathrm{C}, 48 \mathrm{~h}$ drying to get the solid A. Finally, using muffle furnace $580^{\circ} \mathrm{C}$ sintering $4 \mathrm{~h}$ get product.

Rigaku D/Max-2400 X-ray diffract meter was employed to check the phase of the phosphor powder using $\mathrm{CuKaradiation}$ under room temperature. The wavelength is $1.54056 \times 10^{-4}$ um. The scanning electron microscopy (SEM) images of the nanoparticles were obtained by using SEM (JEM-2100F Electron Microscope/JEOL Co.200 $\mathrm{kV}$ ). Measure and adjust $\mathrm{pH}$ value of solution $\mathrm{B}$ using the Sartorius $\mathrm{pH}$ meter adjustment. The solution $\mathrm{C}$ dried by the electric blast oven. Solid A heated by muffle furnace.

\section{B. MTT cell experiment}

Selection of logarithmic phase Hela, $0.25 \%$ trypsin digestion, made into single cell suspension, the density of every hole $3 \times 10^{3}$ vaccinated in 96-well plates (corning Inc, 
NY, USA). Experiment is divided into blank control group and experimental group, the experimental group added a solution containing nano silica concentrations were in complete medium $50 \mu \mathrm{g} / \mathrm{ml}, 40 \mu \mathrm{g} / \mathrm{ml}, 30 \mu \mathrm{g} / \mathrm{ml}, 20 \mu \mathrm{g}$ $/ \mathrm{ml}, 10 \mu \mathrm{g} / \mathrm{ml}$; the blank in the control group only complete medium. The 96 -well plates placed $37{ }^{\circ} \mathrm{C}, 5 \% \mathrm{CO} 2$, in the water-saturated culture incubator, remove $24 \mathrm{~h}$, to which was added $20 \mu \mathrm{L}\left(5 \mathrm{mg} \cdot \mathrm{ml}^{-1}\right)$ of the MTT, placed in an incubator after $4 \mathrm{~h}$ reaction, remove quickly dump hole liquid, add DMSO $150 \mu \mathrm{L}$, oscillating reaction $10 \mathrm{~min}$, measuring wavelength of $570 \mathrm{~nm}$ absorbance values in ELISA analyzer (Bio-Rad, Hercules, CA,USA) on.MTT assay procedure was repeated three more times. Hela cell activity measured by the OD value in laboratory. Calculation of Hela growth inhibition rate by the public (1) to calculate, all the experiment is repeated three times.

$$
\text { [1 - A490 (test)/A490 (control)] x 100\% }
$$

\section{Hoechst 33342 cell staining to observe the influence of nano-silica to Hela apoptosis}

The Hela cells $1 \times 10^{3}$ per well were seeded in 96 -well cell culture plate and the cells were divided into control and experimental groups. After being adherent cells, added the blank control group to the complete medium; the experimental groups were having a concentration of $50 \mu \mathrm{g} \cdot \mathrm{ml}^{-1}, 40 \mu \mathrm{g} \cdot \mathrm{ml}^{-1}$, complete culture $30 \mu \mathrm{g} \cdot \mathrm{ml}^{-1}$, $20 \mu \mathrm{g} \cdot \mathrm{ml}^{-1}, 10 \mu \mathrm{g} \cdot \mathrm{ml}^{-1} \mathrm{SiO}_{2}$ nanoparticles base cultured $24 \mathrm{~h}$. After incubation, abandon culture absorption and clean three times with PBS buffer, each time for 5 minutes. Observed under inverted phase contrast microscope (push around - DP72).

\section{Statistical analysis}

Using SPSS 20.0 statistical software for statistical analysis. Pairwise comparisons using $\mathrm{t}$ test, $\mathrm{P}<0.05$ was considered statistically significant

\section{RESULT AND DISCUSSION}

\section{A. The sample analysis of the XRD and surface photopography}

Fig. 1 shows the XRD pattern of the samples. As can be seen from the figure, all samples are single phase, the strongest peak position are same with the standard JCPDF NO 75 -. 0923, with the increase of $\mathrm{pH}$, the width of the diffraction peak change constantly.

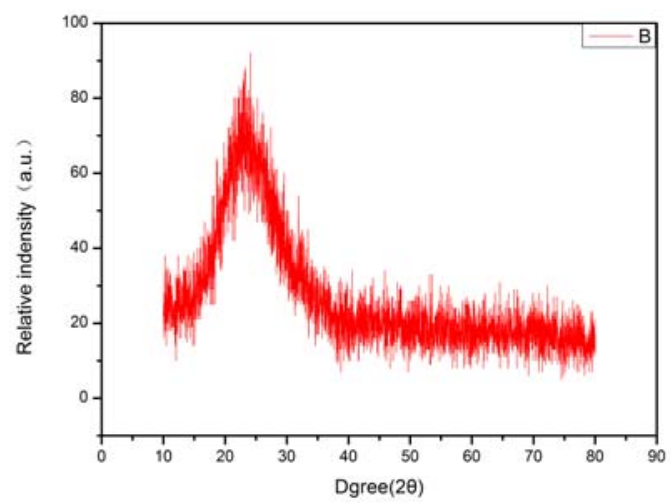

Figure 1.XRD of nano silica sample

From the figure 2 we can know that the sample particle size is about $200 \mathrm{~nm}$. We can see that sample have good dispersibility, smaller particle size and a better morphology, it is because that we improved the experiment process to reduce the concentration of reaction system, adjusted the $\mathrm{pH}$ and did the ultrasonic dispersion, so that the morphology and particle size of the silica balls changed when they formed.

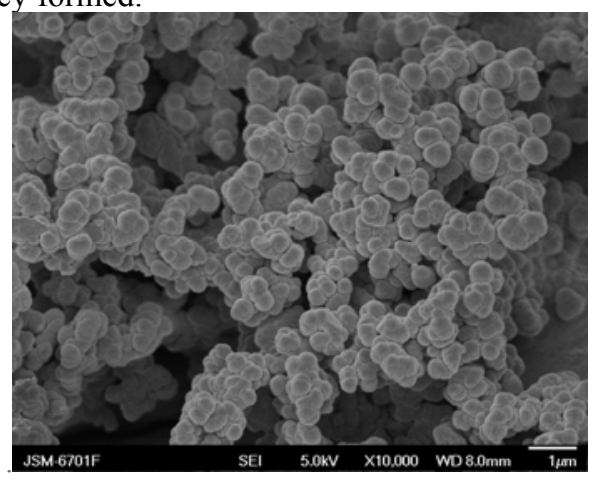

Figure 2.The best sample's TEM photo

\section{B. The analysis of nano-silica sample for Hela cells toxicity}

Figure 3 shows that Hela cell survival rate of different concentrations of $\mathrm{SiO}_{2}$ group were higher than $89 \%$, after $24 \mathrm{~h}, 48 \mathrm{~h}$ period nano silica spheres and Hela increased as the concentration of $\mathrm{SiO}_{2}$ training to $48 \mathrm{~h}$. There was significant difference in comparison $(\mathrm{P}<0.05)$, between the control group $50 \mu \mathrm{g} \cdot \mathrm{ml}^{-1}$ and $40 \mu \mathrm{g} \cdot \mathrm{ml}^{-1} .30 \mu \mathrm{g} \cdot \mathrm{ml}^{-1}, 20 \mu \mathrm{g} \cdot \mathrm{ml}^{-1}$ group and $10 \mu \mathrm{g} \cdot \mathrm{ml}^{-1}$ group compared with blank control group had no statistical difference $(\mathrm{P}>0.05)$. The nano silica spheres had no strong stimulating effect on the growth of Hela. At the concentration of $10 \mu \mathrm{g} \cdot \mathrm{ml}^{-1}$, the comparison with the control group, and its influence is more weak, indicating that the cell has good cell compatibility. 


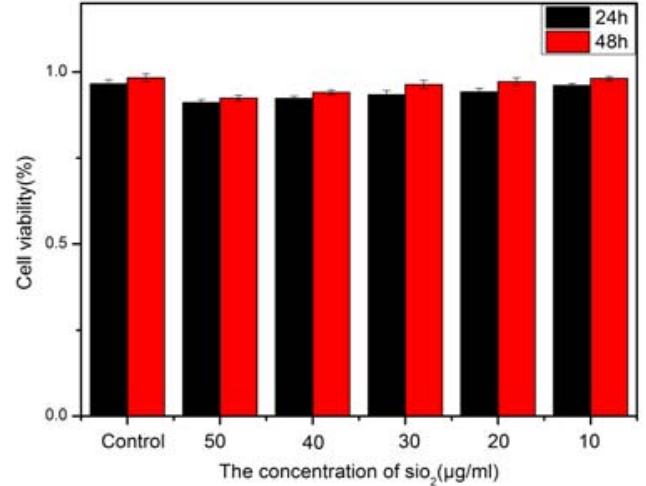

Figure 3. MTT assay in different concentrations of 200nm SiO2 combined with Hela cells

Figure 4 shows the photo which was the Hela cells affected by the different concentrations of nano silica ball for $24 \mathrm{~h}$. The photo was observed by an inverted microscope. It is observed that Hela cells were morphologically normal structure, continued to show a long spindle and no large areas of abnormal death. It is possible to observe a $10 \%-15 \%$ of the cells of the bubble formation of apoptotic bodies, off the wall of death, at a nano-silica concentration of $50 \mu \mathrm{g} \cdot \mathrm{ml}^{-1}$.At the $10 \mu \mathrm{g} \cdot \mathrm{ml}-1$ concentration of the nano-silica the 97 percent of Hela cells are normal cell structure, and there are no significant difference with the control group.
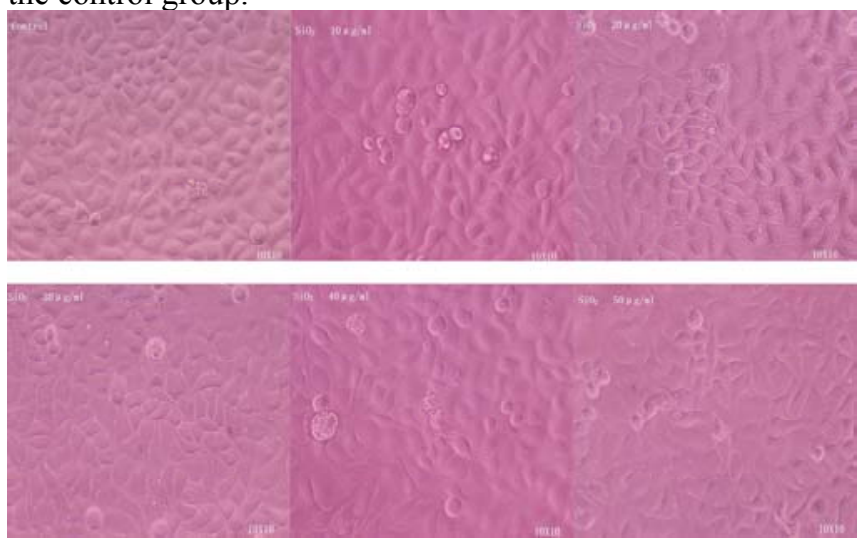

Figure 4. The photo which was the Hela cells affected by the different concentrations of nano silica for $24 \mathrm{~h}$.

Figure 5 shows the Hela cells' stained photos in different concentrations of $\mathrm{SiO}_{2}$ after 24h.Dyed the Hela cells with Hoechst 33342.Form the photo we can see that the Hela cells treated with different concentrations $\mathrm{SiO}_{2}$ ball after $24 \mathrm{~h}$, the concentrated nucleus and small, round apoptotic bodies can be seen occasionally at a concentration of $50 \mu \mathrm{g} / \mathrm{ml}$, Hela structure is normal, nuclear is complete, and the cells dispersed normally when the concentrations is less than $30 \mu \mathrm{g} / \mathrm{ml}$. It follows that $\mathrm{SiO}_{2}$ in low concentrations have no apparent toxicity on Hela cells.

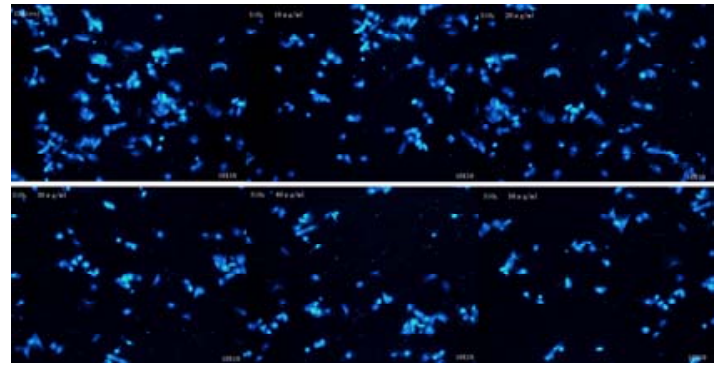

Figure 5. Hela cells' stained photos in different concentrations of $\mathrm{SiO} 2$ after $24 \mathrm{~h}$.

\section{CONCLUSION}

Series samples are synthesized by TEOS hydrolysis method, all samples are single phases and particle sizes are approximately $200 \mathrm{~nm}$ and surface morphology are spherical. Factors that affect the particle size of the sample are magnetic stirring rate and $\mathrm{pH}$ of the reaction solution. But the big size sample have reunion phenomenon, this is because the reactant concentration of the system was too high and the samples have not been treated by ultrasonic dispersion after generated. We confirmed through the experiment, the inhibition of nano silica to the proliferation in vitro of the Hela cells is weak. Cultured the Hela cells $48 \mathrm{~h}$ at these concentrations of nano silica: $50 \mu \mathrm{g} / \mathrm{ml}, 40 \mu \mathrm{g} / \mathrm{ml}$, $30 \mu \mathrm{g} / \mathrm{ml}, 20 \mu \mathrm{g} / \mathrm{ml}$ and $10 \mu \mathrm{g} / \mathrm{ml}$. Nano silica cultured Hela cells $48 \mathrm{~h}$, the survival rate of each concentration group was more than $89 \%$.Observed by inverted phase contrast microscope, Hela structure is normal, no abnormal death. MTT cytotoxicity assay showed that the data of $24 \mathrm{~h} / 48 \mathrm{~h}$ confirmed that the nano silica has smaller influence on the growth of Hela, has good biological compatibility and can be used as potential controlled release drug carrier.

\section{REFERENCES}

[1] Liyi Shi,Bin Hua,Jianping Zhang.The structure of microemulsion and its application in the preparation of ultrafine particles.[J].Functional materials.(1998).p.136-140

[2] Zhi Wang,Chongqing Wu,Hongjing Zhao,etc. Research of the high purity superfine $\mathrm{SiO}_{2}$ powder preparation technology, $[\mathrm{J}]$. journal of railway. vol.12,(1998).p.56-62.

[3] Hong Jia,Kai Guo, Fen Guo etc.The super gravity preparation of nano-silica. [J]. Journal of materials research .Vol.11,(2001).p.17-21.

[4] Yu Guo ,Hongmei Wu , Guili Yin. Sol-gel Preparation of Nano silica .[J].Tianjin Chemical, vol. 39,(2005).p.336-341.

[5] Yifeng He, Wenbin Xu,Liying Bing,Binyuan Luo, Yujuan Li,Wanying Xiao.Research progress of preparation of nano-silica powders. [J].Materials development and application, (2008).p.187-201.

[6] Guobin Li, Yanli Ma,Xinying Kang,Yi Su. Technical progress of $\mathrm{SiO}_{2}$ nanoparticles' preparation.[J].New Chemical Materials, vol. 39,(2011).p.177-182.

[7] Widder K J.Magnetic microspheres: a vehicle for selective targeting of drugs[J]. Pharmacol Ther,(1983),p.133-145

[8] Jun Li, Kemin Wang, Xiaoxiao He. Nanometer scale and single molecular level of chemical biology studies [J]. Journal of university chemistry,vol.3(2004).p.11-15.

[9] Shiguo Zhu,Ke Tang , Juanjuan Xiang.The development and application of biological fluorescent silica nanoparticles [J]. Journal of physical chemistry,vol12,(2003),p.311-314.

[10] Q. He, J. Shi. Mesoporous silica nanoparticle based nano drug 
delivery systems: synthesis, controlled drug release and delivery pharmacokinetics and biocompatibility [J].J.Mater.
[C. Chem,vol.21(2011),p.5845-5855.

[11]Q. He, J. Shi, X. Cui, J. Zhao, Y.Chen and J.Zhou, J.Rhodamine B-co-condensed spherical SBA-15 nanoparticles: facile co-condensation synthesis and e-xcellent fluorescence features [J].Mater. Chem, vol.19(2009),p.3395-3403.

[12] Xiao Lin, Fu Cong, Liang Si-si, Mao Cai-xia, Xi Zhu-ge, Yang Xu. Cytotoxicity Effects of Nano- $\mathrm{SiO}_{2}$ and Normal $\mathrm{SiO}_{2}$ Particles on Hela Cells. Asian Journal of Ecotoxicology,Vol.2 (2007),p.435-439.

[13]Qilu Wang.The research of CTAB@ $\mathrm{SiO}_{2}$ nano composites as gene transfection vectors.[J] Central south university.vol.2(2012).p.25-38.

[14]Yanrong Gao, Yuqiao Jia, Yongdong Zhao,Chunxia Wang,Shanshan Zheng,Feiyu Yang. Nano and micro $\mathrm{SiO}_{2}$ on A549 cell toxicity and the influence of inflammatory factor secretion. [J]Environmental Hygiene Magazine.vol.4(2014),p.518-522.

[15]DeYun Bu,Zhaodi Qiu,Danian Tian,Lingqin Zhu,Herong Liu,Wenwu Ji,Jian Zhou,Huifang Yang. Comparative research of nanometer silica and mesoporous silica on umbilical vein endothelial cell toxic effect.[J]Environmental and occupational medicine. (2014).P.28-32. 